\title{
PERSEPSI PEREMPUAN BEKERJA PADA IKLAN TEH SARIWANGI VERSI "MARI BICARA-TEMPAT FAVORIT" (STUDI WACANA GENDER PADA MEDIA IKLAN TELEVISI)
}

\author{
PERCEPTION OF WORKING WOMEN TOWARDS ADVERTISING SARIWANGI \\ TEA VERSION "LET'S TALK : FAVORITE PLACE" (STUDY OF GENDER \\ DISCOURSE ON TV COMMERCIALS)
}

Yuyun Agus Riani ${ }^{1}$, Nisa Alfira ${ }^{2}$, Reny Yulianti ${ }^{3}$.

\begin{abstract}
ABSTRAK
Terrepresentasi dalam iklan Sari Wangi versi "Mari Bicara-Tempat Favorit", dimana perempuan menjadi inisiator penyelesaian sekaligus memerankan fungsi melayani. Disisi lain, iklan ini juga memvisualkan adanya perbedaan pemaknaan istilah "Tempat Favorit" antara laki-laki (tempat tidur) dan perempuan (restoran). Penelitian ini mengidentifikasi persepsi perempuan menikah bekerja tentang iklan teh Sariwangi "Mari bicara-Tempat Favorit" : a. Isi cerita iklan adalah karakter budaya keluarga Indonesia, b. Peran perempuan melayani suami sudah tepat, c. Perempuan harus proaktif dalam penyelesaian masalah keluarga karena laki laki kecenderungan membiarkan, d. Laki-laki mempersepsi hubungan suami istri adalah hubungan seks, sehingga kata favorit merujuk pada tempat tidur, sedangkan perempuan berpersepsi tempat favorit adalah tempat romantis (restoran untuk makan malam).

Kata Kunci : Gender dan media, persepsi, perempuan bekerja, iklan TV
\end{abstract}

\begin{abstract}
Its value presented in Sari Wangi's "Let's Talk-Place Favorite" advertisement, where women become the initiator of completion as well as the role of serving service. On the other hand, this ad also visualizes the different meaning of the term "Favorite Place" between men (bed) and women (restaurant). This study identify the perception of working married women about Sariwangi tea advertisement "Let's talk-Favorite Place": a. The content of the ad story is the character of Indonesian family culture, $b$. The role of women serving husbands is appropriate, $c$. Women should be proactive in solving family problems because men tend to let, $d$. Men perceive the relationship of husband and wife is sex, so favorite word refers to the bed, whereas women are perceived a favorite place is a romantic place (restaurant for dinner).
\end{abstract}

Keywords: Gender and media, perception, working women, TV commercials

\footnotetext{
${ }^{1}$ Communication Science Department, Brawijaya University, yuyunriani@ub.ac.id

${ }^{2}$ Communication Science Department, Brawijaya University

${ }^{3}$ Communication Science Department, Brawijaya University
} 


\section{PENDAHULUAN}

Budaya patriarki pada etnis Jawa mengintepretasikan laki-laki memiliki peran dominan dibanding perempauan dalam keluarga, sehingga hal ini berdampak pada representasi peran laki-laki dan perempuan terbedakan dalam kontruksi sosial. Dalam hal hubungan laki-laki dan perempuan, suami dalam keluarga Indonesia dikontruksikan dominan aktif dipublic area sedangkan perempuan didomestic area, selain itu seringkali perempuan menjadi objectivasi dalam istilah seks. Hal ini salah satunya terepresentasi dalam pesan-pesan yang tersampaikan dalam berita, film, iklan, dan media baru.

Banyak sekali iklan-iklan televisi yang kemudian menjadi sangat populer entah karena alur cerita dalam Iklan, tokoh iklan, music iklan, audio ataupun visual iklan itu sendiri. Diantaranya sangat khas dan mencerminkan budaya patriarki di Indoensia, contohnya iklan peralatan rumah tangga sebagian besar diperankan perempuan, sementara iklan otomotif, perbankkan diperankan oleh laki-laki.

Isu gender lainya adalah pengambilan keputusan dalam keluarga, seperti disampaikan dari hasil penelitian yang dilakukan Ida dan Henky Lisan S, dari Fakultas Ekonomi, Universitas Kristen Maranatha, Bandung bahwa pada intinya, asumsi dasar dari perolehan kepatuhan adalah bahwa pada setiap interaksi antar manusia selalu memunculkan apa yang disebut "power relationship" atau hubungan kekuasaan (Rakhmat,2000:163, dalam Ida dan Henky, 2011). Power relationship sendiri dimaknai sebagai adanya pihak lain yang mempengaruhi dan dipengaruhi. Budaya patriarki menempatkan perempuan dalam dominasi laki-laki dimana sistem sosial memposisikan laki-laki lebih utama dan mendapat pelayanan perempuan. Perempuan Jawa diperkirakan sudah bergeser perannya, tidak lagi menjadi "koncowingking" atau istilahnya "suargo nunut neroko katut", tetapi telah memiliki bargaining power dalam memutuskan persoalan tumah tangga (Ida dan Henky, 2011). Hal ini juga dituangkan dalam iklan Sari Wangi dengan versi "Mari Bicara", dimana ketika muncul sebuah persoalan dalam keluarga maka perlu mendiskusikan persoalan tersebut bersama untuk saling memahamkan dan mencari solusi. Dalam organisasi bernama keluarga ini maka permepuan harus berjuang sendiri untuk mengambil hak-haknya berpendapat 
dan kekuasaan hubungan dengan suaminya. Memahami beberapa fenomena dan intepretasi diatas penelitian mengidentifikasi persepsi perempuan bekerja pada iklan teh sariwangi versi "Mari Bicara : Tempat Favorit" dalam perspektif gender. Penelitian ini bertujuan untuk mendeskripsikan pendapat pikiran perempuan bekerja tentang isu dan wacana gender, melakukan "Critical Thinking” atau pemikiran kritis bersama perempuan bekerja p dan memberikan penyadaran kepada perempuan Indonesia untuk responsif terhadap pesan media.

\section{A. Komunikasi}

Menurut William C. Himstreet dan Wayne Murlin Baty, komunikasi adalah suatu proses pertukaran informasi antarindividu melalui suatu sistem yang biasa (lazim) baik dengan simbol-simbol, sinyal-sinyal, maupun perilaku atau tindakan (Purwanto, 2003: 3). Berdasarkan definisinya, komunikasi paling tidak melibatkan dua pihak atau lebih yang saling menyampaikan dan menerima pesan baik secara verbal maupun nonverbal.

Komunikasi verbal adalah Simbol atau pesan verbal adalah semua jenis simbol yang disampaikan dengan menggunakan kata atau bahasa, baik secara lisan maupun tertulis. Bahasa adalah system kode verbal, karena bahasa dapat didefinisikan sebagai seperangkat simbol, dengan aturan untuk mengkombinasikan simbol-simbol tersebut, yang digunakan dan dipahami suatu komunitas (Mulyana, 2005: 237-238).

Sedangkan komunikasi non verbal menurut ilmu antropologi, sebelum mengenal adanya sistem bahasa, manusia telah terlebih dahulu berkomunikasi dengan orang lain menggunakan gerakan tubuh atau bahasa tubuh (body language). Gerakan-gerakan tersebut disebut dengan komunikasi nonverbal. Dalam hubungannya dengan perilaku verbal, perilaku nonverbal mempunyai fungsi-fungsi sebagai berikut (Mulyana, 2005: 314):

1. Perilaku nonverbal dapat mengulangi perilaku verbal. 
2. Perilaku nonverbal dapat memperteguh, menekankan, atau melengkapi perilaku verbal.

3. Perilaku nonverbal dapat menggantikan perilaku verbal.

4. Perilaku nonverbal dapat meregulasi perilaku verbal.

Mulyana (2005) mengklasifikasikan perilaku nonverbal ke dalam beberapa kategori sebagai berikut: a). Bahasa Tubuh, b). Sentuhan, c). Parabahasa, d). Penampilan Fisik, e). Bau-bauan, f). Orientasi ruang dan jarak pribadi, g).Konsep waktu, h). Diam, i). Warna, dan j). Artefak

\section{B. Periklanan}

Periklanan merupakan salah satu cara yang dilakukan oleh perusahaan untuk meningkatkan hasil penjualan. Periklanan adalah setiap bentuk penyajian dan promosi barang, jasa atau ide oleh sponsor tertentu, dan promosi tersebut bersifat non personal (Alma, 1992: 140). Fungsi Periklanan dianggap penting oleh perusahaan karena periklanan dikenal sebagai pelaksana beragam fungsi komunikasi yang penting bagi perusahaan bisnis dan organisasi lainnya. Fungsi-fungsi periklanan menurut Shimp (2003: 361) tersebut adalah: a). Informing , b). Persuading, c). Reminding, d). Adding Value, dan e).

Media televisi memiliki dua unsur di dalamnya, yaitu gambar (visual) dan suara (audio). Tidak seperti media massa lainnya, yaitu radio dan media cetak yang hanya berisi suara saja atau gambar saja, televisi unggul di kedua unsur tersebut. Sehingga iklan yang menggunakan media televisi lebih banyak menarik perhatian konsumen 
Pesan dalam iklan TV merupakan unsur penting, seperti disampaikan Kotler (1997b: 212) menyatakan bahwa pesan harus menarik perhatian (attention), mempertahankan ketertarikan (interest), membangkitkan keinginan (desire), dan menggerakkan tindakan (action).

\section{Persepsi}

Persepsi merupakan pengalaman tentang objek, peristiwa, atau hubungan-hubungan yang diperoleh dengan menyimpulkan informasi dan menafsirkan pesan. Persepsi adalah suatu proses pemberian makna pada rangsangan atau stimuli yang ditangkap oleh panca indera (Rakhmat, 2004: 51). Proses pembentukan persepsi terdiri dari lima tahapan (Devito, 2007: 81), yaitu: a). Stimulation, b). Organization, c). InterpretationEvaluation, d). Memory, e). Recall. Persepsi manusia sendiri dipengaruhi oleh kebutuhan , pengalaman masa lalu, yang ini disebut Faktor Fungsional (Rakhmat, 2009: 56). Faktor lainya yang membentuk persepsi adalah faktor Struktural, dimana Faktorfaktor struktural berasal dari sifat stimuli fisik dan efek-efek saraf yang ditimbulkannya pada sistem saraf manusia.

Berdasarkan pemikiran-pemikiran diatas penelitian ini menempatkan Iklan TV tesh Sariwangi versi "Mari bicara: Tempat favorit" merupakan stimulus utama yang dipersepsi oleh audience. Unsur-unsur iklan yang dipersepsikan adalah pesan, peran pendukung dalam iklan, gambar dan musik iklan, dan naskah iklan.

\section{METODE PENELITIAN}

Penelitian ini menggunakan paradigma interpretatif yaitu melakukan pemaknaan atas pengalaman sehari-hari individu dengan perilaku sosialnya (Neuman, 200: 71). Paradigma ini sesuai digunakan dalam penelitian ini, karena peneliti ingin melihat bagaimana informan dalam penelitian menginterpretasikan tanda-tanda yang terdapat dalam sebuah iklan sehingga menghasilkan persepsi tertentu mengenai suatu produk yang diiklankan. Dalam penelitian ini, penulis memilih dan menggunakan jenis

penelitian kualitatif, mengutip Kirk dan Miller yang mendefinisikan penelitian kualitatif 
sebagai tradisi tertentu dalam ilmu pengetahuan sosial yang secara fundamental bergantung pada pengamatan pada manusia dalam kawasannya sendiri dan berhubungan dengan orang-orang tersebut dalam bahasa dan peristilahannya (Nurastuti, 2007: 90). Sedangkan jenis penelitian kualitatif yang digunakan adalah jenis deskriptif, yang bertujuan membuat deskripsi secara sistematis, faktual, dan akurat tentang fakta-fakta dan sifat-sifat populasi atau objek tertentu (Kriyantono, 2007: 69).

Fokus dalam penelitian ini adalah a).Persepsi perempuan terhadap isi cerita iklan, b). Persepsi perempuan pada pembuat teh., c). Persepsi perempuan terhadap inisiator, d). Persepsi perempuan pada istilah "Tempat Favorit". Peneliti merupakan Instrumen utama yang melakukan penelitian lapang (Kriyantono, 2007: 59). Teknik sampling yang digunakan adalah purposive sampling, yaitu teknik pengambilan sampel sumber data dengan pertimbangan karakter tertentu (Sugiyono, 2004: 218). Dengan menggunakan teknik pengeumpulan data wawancara terstruktur penelitian ini memilih informan sesuai kriteria: a). Perempuan dewasa awal dan dewasa akhir, b). Minimal 2 tahun bekerja, c). Menikah minimal selama 5 tahun.

Dalam analisis data peneliti menggunakan teknik analisis data milik Miles dan Huberman (Sugiyono, 2004: 246), mengemukakan bahwa aktivitas dalam analisis data kualitatif dilakukan secara interaktif dan berlangsung secara terus menerus sampai tuntas, sehingga datanya sudah jenuh. Adapun aktivitas dalam analisis data, antara lain (Sugiyono, 2004: 249) : a). Reduksi Data, b). Penyajian Data, c). Verifikasi

\section{HASIL DAN PEMBAHASAN}

Penelitian ini melibatkan 6 informan perempuan bekerja yang terdiri dalam dua kelompok usia, yaitu dewasa awal 25-35, dan kelompok berikutnya dewasa akhir usia 35-50 tahu. Temuan dan analisis dikelompokkan dalam empat poin sesuai dengan empat fokus penelitian yaitu: (i) persepsi perempuan terhadap isi cerita iklan Teh Sariwangi "Mari Bicara-Tempat Favorit" versi Tempat Favorit; (ii) persepsi perempuan terhadap figur pembuat teh dalam iklan; dan (iii) persepsi perempuan terhadap 
inisiator pengambil keputusan pada iklan teh tersebut; (iv) persepsi perempuan terhadap makna "tempat favorit"

\section{A. Persepsi perempuan terhadap isi cerita iklan Teh Sariwangi "Mari Bicara- Tempat Favorit" versi Tempat Favorit}

Penelitian mendapatkan bahwa perempuan bekerja mempersepsi isi cerita pada iklan ini sebagai cerita yang cukup bagus. Dari segi alur, informan menyatakan bahwa memang alur ceritanya relatif berjalan cepat namun masih bisa dipahami. Iklan ini dipersepsikan sebagai iklan yang baik, karena tidak hanya menawarkan produk teh namun juga menggambarkan tawaran pesan bahwa permasalahan rumah tangga bisa diselesaikan dengan cara dialog. Berkaitan dengan alur cerita iklan yang mudah dipahami, karena diawali dengan suami istri yang saling ber sms untuk bertemu di “ Tempat Favorit" jam 7 malam, namun akhirnya masing masing mengintepretasi "Tempat Favorit" sangat berbeda. Tentang isi iklan ini, informan mempersepsi cenderung positif, meskipun terdapat satu orang informan yang mempersepsi bahwa iklan ini kurang mempromosikan teh Sariwangi sebagai produk yang dipromosikan.

Setting tempat supermarket pada iklan ini dipersepsi kurang tepat sebagai tempat berbelanja, dan sebagian lagi dianggap tepat karena mencerminkan peran dan figur istri yang rajin dalam mengurus kebutuhan rumah tangga. Namun pemilihan setting rumah sebagai tempat penyelesaian masalah (terjadinya dialog antarsuami-istri) dipersepsi tepat karena rumah adalah tempat yang paling tepat untuk menyelesaikan masalah bagi keluarga.

Aktor pemeran iklan the sariwangi versi " Tempat Favorit" ini dipersepsikan sesuai dengan karakter keluarga di Indonesia dimana istri terlihat lebih muda, sederhana, lembut, sabar , sedang suami lebih tua. Hanya saja ada yang anek karena iklan ini tidak menampilkan adanya anak-anak dalam rumah tangga, walau sebagian informan mendukung iklan ini tanpa figur anak karena tema yang diangkat sangat dewasa.

\section{B. Persepsi perempuan pada figur pembuat teh pada adegan iklan.}


Para informan mempersepsikan bahwa dari segi usia, figur istri sekaligus pembuat teh dalam iklan ini berusia lebih muda, sederhana, lembut, dan penyabar dibanding figur suami yang terlihat marah setelah menunggu ditempat favorit yang berbeda. Peran suami yang memberi perhatian dengan mengajak bertemu di"tempat Favorit" ini dipersepsi sebagai figur suami yang baik, selain itu juga suami yang mau menata tempat tidur dipersepsi sebagai suami yang baik. Namun dalam dunia nyata, informan membandingkan peran suami dalam iklan dengan yang ada disekitar mereka, biasanya istri yang selalu melayani suami dan keluarga, sosok suami jarang yang mau mengambil bagian dalam kegiatan rumah tangga, karena pekerjaan rumah tangga menjadi tangguang jawab istri. Selain itu Istri juga dipersepsikan sebagai pihak superordinat dalam keluarga, pihak yang selalu melayani oleh istri dan bukan sebaliknya, unutk itulah lazim dalam iklan tersebut istri yang mebuatkan teh buat suami.

Alur cerita dalam iklan ini juga dianggap sangat mencerminkan kondisi sosial keluarga diindonesia, dimana laki-laki sangat menyukai urusan " ranjang” (seksual), bekerja (mencari nafkah), istri belanja dan melayani suami. Dalm keistilahan "tempat Favorit" istri yang memilih restoran favorit itu menceriminkan bahwa perempuan dalam hubungan suami istri lebih mementingkan perhatian romantis.

\section{Persepsi perempuan terhadap istri yang pengambilan keputusan menyelesaikan masalah}

Dalam iklan ini, perempuan digambarkan mengambil inisiatif terlebih dahulu ketika terjadi kesalahpahaman dengan suaminya karena perbedaan persepsi mengenai "tempat favorit". Ketika keduanya tidak saling bicara, sang istri memulai berinisiatif dengan berpikir "Daripada nggak enak begini, mending diomongin aja" lalu ia membuat dua cangkir teh untuk ia dan suami. Kemudian ditunjukkan dalam scene bahwa ia pun yang memulai pembicaraan dengan menyampaikan "Ayah, tadi aku nunggu di restoran favorit kita Iho". Dari situlah kemudian suasana terlihat mencair ketika sang suami menanggapi, "Oh kirain ketemu disini” dan keduanya kemudian tertawa. 
Menurut para informan, sang istri dipersepsikan berperan besar sebagai inisiator untuk menyelesaikan masalah, hal ini sesuai dengan pengalaman nyata di dunia rumah tangga yaitu mereka mencoba memulai inisiatif berbicara ketika ada kesalahpahaman yang terjadi diantara mereka dengan suami. Mereka tidak suka bila ada permasalahan yang "mengganjal" sehingga terjadi kebekuan antara suami istri dan kemudian berlarut menjadi masalah yang lebih besar. Namun disisi lain, informan menyatakan bahwa seringkali suami justru bisa saja tidak mau memulai pembicaraan. Hal ini disesuaikan dengan pengalaman nyata mereka, dimana mereka akhirnya berpersepsi bahwa pria lebih banyak menggunakan rasio sedangkan perempuan lebih peka dalam menggunakan perasaan (emosi). Ada salah satu informan yang mempersepsi bahwa inisiator penyelesaian masalah haruslah berimbang, tidak harus dari istri terlebih dulu. Informan lain yang sejalan dengan pendapat ini, menyatakan bahwa penyelesaian masalah tergantung pada siapa yang "memulai masalah". Artinya, bila masalah ditimbulkan oleh suami, maka suami yang harus memulai menyelesaikan masalah, demikian juga sebaliknya. Terdapat juga informan yang berpendapat bahwa dalam dunia rumah tangga sebagaimana yang ia alami, sosok istri harus menjadi pihak yang mengalah. Informan tersebut mendapat pengetahuan dari pendidikan keluarganya bahwa istri harus mengabdi pada suami. Hal ini berimbas pada sifat mengalah yang harus dimilikinya sebagai seorang istri.

Terkait inisiator penyelesai masalah dalam keluarga dalam iklan tersebut dipengaruhi oleh latar belakang masing-masing. Bagi informan yang terdidik untuk harus mengalah, maka ia merasa harus memulai inisiatif lebih dulu untuk menyelesaikan masalah meskipun mungkin saja ia tidak sebagai pihak yang bersalah. Namun ada informan lain yang berpendapat bahwa penyelesaian masalah harus berimbang, tidak harus istri terlebih dulu yang memulai inisiatif menyelesaikan masalah, atau dikembalikan kepada siapa yang terlebih dulu membuat kesalahan maka ia-lah yang harus bertanggungjawab menyelesaikannya.

\section{Persepsi perempuan terhadap makna "tempat favorit".}

Istilah "tempat favorit" dalam iklan the sariwangi ini dipersepsi bahwa laki-laki berkecenderungan orientasi hanya seks dalam hubungan romantis. Sementara 
perempuan, romantis itu dimaknai dengan kata-kata yang manis, perlakukan romantik yang tidak mengkait dengan istilah seks. Seperti disampaikan oleh salah satu informan ibu Ani ketika ditanya makna tempat favorit dalam iklan, " yah itu biasa ...laki-laki emang gitu, kalo sudah menikah yah urusanya sama "itu" (seks)..mana ada manis manis? Jarang...". Perempuan selalu mengingat hal-hal favorit (indah) dalam hubungan suami istri, sementara suami dianggap mudah melupakan.

\section{KESIMPULAN DAN SARAN}

Penelitian ini menyimpulkan bahwa persepsi perempuan terhadap isi iklan positif, mereka mempersepsikan isi iklan mencerminkan situasi rumah tangga pada umumnya di Indonesia dimana kesalahpahaman antara pasangan suami-istri dapat diselesaikan melalui dialog. Selain itu persepsi terhadap figur istri sebagai pembuat teh pada iklan dianggap sesuai dengan kondisi keluarga Indonesia pada umumnya, karena istri dipersepsikan sebagai pengurus keperluan rumah tangga dan melayani suami. Sedangkan menanggapi gambar iklan yang menempatkan istri sebagai inisiator pengambil keputusan penyelesaian masalah penelitian ini menemukan perempuan bekerja berpendapat bahwa hal ini juga yang dialami dalam kehidupan nyata mereka, bahwa setiao ada maslaah istri harus mengalah demi menyelesaikan masalah rumah tangga. Pemaknaan terghadap istilah "tempat favorit" teridentifikasi bahwa persepsi perempuan bekerja menunjukan bahwa tempat favorit bagi istri adalah tempat romantis, kenangan (restoran kesayangan), sementara kebanyakan suami melihat bahwa tempat favorit adalah tempat tidur (aktifitas seks) karena hubungan suami istri bagi laki laki sering diindetikan dengan hubungan seks.

Saran dari penelitian ini bisa dilanjutkan untuk penelitian kontruksi perempuan dalam konstruksi media Indonesia pada seluruh iklan the sariwangi versi "mari bicara". Selain itu juga bisa melakukan kajian komparasi audience iklan perempuan tidak bekerja.

\section{DAFTAR PUSTAKA}

Alma, Buchari. 1992. Manajemen Pemasaran dan Pemasaran Jasa. Bandung: Alfabeta

Devito, Joseph. 2007. The Interpersonal Communication Book 11-th Edition. 
USA: Pearson Educations

Engel F. James, Roger D. Blackwell, Paul W. Miniard. 1995. Perilaku Konsumen. Alih Bahasa F.X Budiyanto. Jilid 2. Edisi Keenam. Jakarta : Binarupa Aksara.

Kasali, Rhenald. 1992. Manajemen Periklanan, Konsep, dan Aplikasinya di Indonesia. Jakarta : Pustaka Utama Grafiti.

Kotler, Philip. 1997. Manajemen Pemasaran. : Analisa, Perencanaan, Implikasi dan Kontrol, Jilid I. Jakarta: PT Prenhallindo

Kriyantono, Rachmad. 2007. Teknik Praktis Riset Komunikasi. Jakarta: Kencana Prenada Media Group

Madjadikara, Agus. S. 2004. Bagaimana Biro Iklan Memproduksi Iklan. Jakarta: Gramedia Pustaka Utama

Moleong, Lexy J. 2009. Metodologi Penelitian Kualitatif Edisi Revisi. Bandung: Remaja Rosdakarya

Mulyana, Deddy. 2005. Ilmu Komunikasi Suatu Pengantar. Bandung: PT. Remaja Rosdakarya 2006. Metodologi Penelitian Kualitatif: Paradigma Baru Ilmu Komunikasi dan Ilmu Sosial Lainnya. Bandung: Remaja Rosdakarya

Nurastuti, Wiji. 2007. Metodologi Penelitian. Yogyakarta: Ardana Media

Purwanto, Djoko. 2003. Komunikasi Bisnis. Edisi Kedua. Jakarta: Erlangga.

Rakhmat, Jalaluddin. 2009. Psikologi Komunikasi. Bandung: Remaja Rosdakarya

Roman Kenerth, Jane Maas, Martin Nisenholtz. 2005. How To Advertise: Membangun Merek dan Bisnis dalam Dunia Pemasaran Baru. Jakarta: PT. Elex Media Komputindo

Shimp, Terence A. 2003. Periklanan dan Promosi : Aspek Tambahan Komunikasi Pemasaran Terpadu. Jilid 1. Jakarta : Erlangga

Sugiyono. 2004. Metode Peneltian Kuantitatif, Kualitatif dan R \& D. Bandung: Alfabeta

Suyanto, M. 2005. Strategi Perancangan Iklan Televisi Perusahaan Top Dunia. Yogyakarta : Andi

Swastha, Basu D. H dan Irawan. 1983. Manajemen Pemasaran Modern Edisi Kedua. Jakarta : Erlangga

Ida dan Henky Lisan S (2010), Pengaruh Tingkat Pendidikan dan Pendapatan Pasangan Suami- Istri Terhadap Pengambilan Keputusan Keuangan Keluarga, Fakultas Ekonomi, Universitas Kristen Maranatha, Bandung 
Umi Listyaningsih (2003), Transformasi Peran Wanita Jawa Dalam Rumah Tangga : Analisis Kewenangan Istri dalam Pengambilan Keputusan Rumah Tangga Berdasarkan Data Sakerti Tahun 1997 dan 2000, Penerbit : Lembaga Penelitian UGM ,Jogjakarta

106 | Persepsi Perempuan Bekerja Pada Iklan Teh Sariwangi Versi... 